\title{
Een gedragsbenadering van ethisch leiderschap
}

Karianne Kalshoven, Deanne N. den Hartog en Annebel H.B. de Hoogh

SAMENVATTING In dit artikel wordt een overzicht gegeven van de onderzoeksliteratuur op het gebied van ethisch leiderschap. Voor ethische leidinggevenden is het belangrijk om het juiste voorbeeld te geven en een vertrouwensband met werknemers op te bouwen. Dit leidt bij medewerkers onder andere tot meer tevredenheid, inspanning, vertrouwen en bereidheid tot rapporteren van problemen aan het management, maar ook tot meer samenwerking en proactiviteit. Vooral leidinggevenden met een hoge mate van sociale verantwoordelijkheid, cognitief morele ontwikkeling en bepaalde karaktereigenschappen zijn geneigd tot het tonen van ethisch leiderschap. Het artikel besluit met de bespreking van praktische implicaties.

RELEVANTIE VOOR DE PRAKTIJK In Nederland is er een vragenlijst ontwikkeld die verschillende aspecten van ethisch leiderschap meet, welke kan dienen als model om het ethisch gedrag in een organisatie in kaart te brengen. Voor organisaties ligt er een uitdaging om leidinggevenden te trainen en ontwikkelen op het gebied van ethisch gedrag om optimaal van de positieve effecten van ethisch leiderschap te kunnen profiteren.

\section{Inleiding}

Ernst \& Young heeft in 2009 een onderzoek gepresenteerd waarin wordt geconcludeerd dat $55 \%$ van de ondervraagde werknemers verwacht dat onethisch gedrag op het werk zal toenemen de komende jaren. Het onderzoek is gehouden onder 2246 werknemers in 22 Europese landen. Onethisch gedrag van medewerkers en leidinggevenden schaadt de reputatie van de organisatie en het zittende management. Aandeelhouders willen niet verbonden zijn met een dergelijke organisatie en ook consumenten reageren door naar concurrenten te gaan. Sinds de kredietcrisis erkennen topmanagers dat beperkte transparantie en een kortetermijncultuur met focus op eigen gewin het vertrouwen in deze organisaties en de branche als geheel schaden.

Het verminderde vertrouwen van de burgers in de financiële sector heeft ook zijn weerslag op beroepsgroepen zoals de accountancy, waar accountants als controleurs van de banken worden aangesproken op de tekortkomingen in het controleproces, met reputatieverlies tot gevolg. Het is dus belangrijk dat beroepsgroepen waar vertrouwen een cruciale rol speelt, bijvoorbeeld in de functies van accountant en controller, zij verantwoordelijk omgaan met de voorbeeldfunctie die zij hebben. Dat betekent dat het bewustzijn onder accountants van de vertrouwensrol en de voorbeeldfunctierol dan ook van groot belang is.

Tot nu toe zijn organisaties op diverse manieren bezig om vorm te geven aan de roep vanuit de landelijke overheid, de burger en de consument tot meer ethisch en verantwoordelijk gedrag. Bedrijfsethiek gaat niet alleen over wettelijke regels, maar ook over beleid dat in lijn is met de normen van de samenleving en de organisatie. Sommige organisaties stellen gedragscodes voor medewerkers op of stellen toezichthouders zoals 'compliance officers' aan. Uit recente ervaringen blijken regels en toezichthouders niet voldoende om ethisch gedrag in een organisatie te waarborgen. Sinds 2005 ligt daarom de nadruk op de rol van leidinggevenden in het vertonen van ethisch gedrag.

De nadruk van dit artikel ligt op stromingen en onderzoeken van ethische gedragsaspecten van leidinggevenden sinds het ontstaan van het vakgebied. In een onderzoek uitgevoerd door KPMG (2010) blijkt dat commissarissen van diverse organisaties het voorbeeldgedrag van directieleden als belangrijkste integriteitkenmerk aanduiden. Vanuit de wetenschappelijke literatuur wordt beargumenteerd dat leidinggevenden het gedrag van medewerkers kunnen sturen door voorbeeldgedrag te tonen, maar ook door te communiceren over de gedragsregels en door ethisch verantwoordelijk gedrag onder werknemers te stimuleren en te belonen. Hoewel integriteit en ethisch gedrag bij organisaties al een aantal jaren een hoge prioriteit hebben, begint de wetenschappelijke kennis over de inhoud, antecedenten en uitkomsten van ethisch leiderschap pas recentelijk te accumuleren. 
Aan de hand van bestaande literatuur wordt in paragraaf 2 uitgelegd wat ethisch leiderschapsgedrag is, hoe het gemeten kan worden en welke theorieën ten grondslag liggen aan het huidige onderzoek op het gebied van ethisch leiderschap. Daarna worden uitkomsten en antecedenten van ethisch leiderschapsgedrag beschreven in respectievelijk paragraaf 3 en 4 . Ten slotte, in paragraaf 5 worden de praktische relevantie en beperkingen van het onderzoeksveld besproken.

\section{Definitie van ethisch leiderschap}

Een filosofische benadering van ethisch leiderschap gaat over normen en waarden en beschrijft wat leiders horen te doen (Ciulla, 2004). Het gebruik van normen en waarden in de benadering van ethisch leiderschap heeft een nadeel. Een leidinggevende met bepaalde normen en waarden hoeft zich daar bijvoorbeeld nog niet naar te gedragen. Ciulla (2004) richt zich in zijn werk op de handelingsgeoriënteerde beginselenethiek en de gevolgenethiek. Beginselenethiek (zoals het deontologisch perspectief) beschouwt het gedrag van leidinggevenden als beoordeling van moraliteit, ongeacht de consequenties. In de gevolgenethiek (zoals het theologisch perspectief) draait het om het ethische resultaat van het gedrag van een leidinggevende, dus het gaat om de consequenties van de handeling van leidinggevenden als beoordeling van moraliteit. Deze twee vormen komen voort uit de deugdenleer en dit is dus ook een filosofische benadering van ethiek, waarbij vier kerndeugden, te weten wijsheid, moed, matigheid en rechtvaardigheid, te onderscheiden zijn. Deugden zijn het karakter van een persoon en dus geen gedrag. Een deugdenbenadering van ethisch leiderschap zou betekenen dat het niet trainbaar is, omdat het karakter van een persoon niet maakbaar is. Voor meer informatie over de deugdenethiek, zie Kaptein (2005). Hij geeft een duidelijke beschrijving van wat de deugdenethiek voor de accountants en controllers kan betekenen. Ethisch leiderschap is meer uit een gedragsbenadering voortgekomen en sluit meer aan bij eerder leiderschapsonderzoek dan bij onderzoek vanuit een ethisch/filosofische discipline. In dit artikel ligt de nadruk op een gedragsbenadering van ethisch leiderschap.

Pas sinds 2005 komt onderzoek naar ethisch leiderschapsgedrag als een apart veld binnen leiderschapsonderzoek echt op gang. Daarvoor lag de nadruk meer op hetzij ethiek in organisaties in brede zin hetzij de ethische aspecten van andere leiderschapsstijlen, zoals de moraliteit van charismatische leiders. Verschillende onderzoeken hebben aangetoond dat ethisch leiderschap samenhangt met leiderschapsstijlen zoals transformationeel en authentiek leiderschap, maar dat deze leiderschapsstijlen ook onderling genoeg onderscheidend zijn (Kalshoven et al., 2010; Walumbwa et al., 2008). In dit artikel rapporteren we voor- namelijk over het onderzoeksveld dat zich specifiek richt op ethisch leiderschap als een apart construct en niet als een element van andere vormen van leiderschap.

Vanuit de gedragsbenadering wordt ethisch leiderschap beschreven als normatief juist gedrag, wat bestaat uit eerlijkheid, betrouwbaarheid, oprechtheid en zorgzaamheid (Brown et al., 2005). Ethische leiders nemen eerlijke beslissingen, behandelen anderen met respect en zorgzaamheid, houden rekening met anderen als ze een beslissing nemen en betrekken werknemers in het nemen van beslissingen die hen treffen (De Hoogh en Den Hartog, 2008; Treviño, Brown en Hartman, 2003; Kalshoven, 2010). Ethische leidinggevenden hebben een voorbeeldfunctie voor de werknemer en hun voorbeeldgedrag bevordert ethisch gedrag binnen de organisatie. Daarnaast kunnen ook communicatie, sancties en beloningen daaraan bijdragen (Brown et al., 2005). Dus leidinggevenden die ethisch zijn, kunnen werknemers stimuleren om ook ethisch te handelen. Ethische leidinggevenden onderscheiden zich door zich rechtvaardig en integer te gedragen en zich verantwoordelijk te voelen voor hun acties en de consequenties van hun acties voor anderen. Deze leidinggevenden gaan op een sociaal verantwoordelijke manier om met de macht die ze hebben in hun positie (De Hoogh en Den Hartog, 2009). Anderen beogen de rol van ethische leidinggevenden in het vormen van een ethisch klimaat te belichten (Dickson et al., 2001). Een ethisch klimaat wordt beïnvloed door leidinggevenden, die expliciet een aantal waarden willen overbrengen op werknemers en dat zorgt voor gedeelde percepties van gewenst gedrag. Ook Kaptein, Rozekrans en De Groot (2005) geven aan dat de rol van een integriteitklimaat als onderdeel van de beheersingsomgeving essentieel is om het controlebewustzijn van de medewerkers te beïnvloeden. In de volgende paragraaf gaan we dieper in op de gedragingen die tot het ethisch-leiderschapsdomein behoren.

\subsection{Dimensies van ethisch leiderschap}

In eerder empirisch onderzoek is nagegaan welke factoren medewerkers en leidinggevenden aangeven als ethische gedragscomponenten. Clustering van deze factoren heeft geleid tot een model met zeven dimensies (Kalshoven et al., 2010), waarmee het ethisch gedrag van leidinggevenden of afdelingen in kaart kan worden gebracht. Deze zeven gedragsdimensies zijn: 1) eerlijkheid en rechtvaardigheid, 2) integriteit, 3) zorgzaamheid, 4) delen van beslissingen, macht en verantwoordelijkheid, 5) begeleiden en stimuleren van ethisch gedrag, 6) verhelderen van verwachtingen, rechten en plichten van medewerkers, en 7) aandacht hebben voor bredere belangen zoals het milieu (zie bijvoorbeeld De Hoogh en Den Hartog, 2009; Kalshoven, 2010; Kalshoven et al., 2010; Resick et al., 2006). Des te meer ethische gedragsfacetten een leidinggevende tot zijn/haar 
Tabel 1 Ethisch leiderschapsgedrag

\begin{tabular}{|l|l|}
\hline Ethisch leiderschapsgedrag & Voorbeelditem \\
\hline Rechtvaardigheid en eerlijkheid & Mijn leidinggevende is voornamelijk gericht op het behalen van zijn/haar eigen doelen. \\
\hline Integriteit & Mijn leidinggevende kan geloofd worden als hij/zij zegt iets te zullen doen. \\
\hline Zorgzaamheid & Mijn leidinggevende heeft specifieke aandacht voor mijn persoonlijke behoeften. \\
\hline Delen van beslissingen & Mijn leidinggevende staat toe dat medewerkers belangrijke beslissingen beïnvloeden. \\
\hline Begeleiden van ethisch gedrag & Mijn leidinggevende geeft duidelijke uitleg over de gedragsregels betreffende integriteit. \\
\hline Verduidelijken van rechten en plichten & Mijn leidinggevende maakt duidelijk wie waarvoor verantwoordelijk is. \\
\hline Aandacht voor milieuzaken & Mijn leidinggevende stimuleert hergebruik van spullen en materialen op onze afdeling. \\
\hline
\end{tabular}

Gebaseerd op Kalshoven et al., 2010

beschikking heeft, des te beter is het voorbeeldgedrag in de organisatie. Het voorbeeldgedrag van een ethische leidinggevende is erg belangrijk in een grijs gebied, waar het niet meteen duidelijk is wat goed of fout gedrag is en door het juiste voorbeeldgedrag te tonen, wordt de weerbaarheid voor onethisch gedrag verhoogd. Hierna volgt een beknopte conceptuele weergave van de dimensies.

Onder zorgzaamheid wordt verstaan dat leidinggevenden oog hebben voor wat belangrijk is voor hun medewerkers en geïnteresseerd zijn in wat er in hun leven speelt. Bij rechtvaardigheid draait het erom dat medewerkers eerlijk en fair behandeld worden. Verder is een ethische leidinggevende integer, dat houdt in dat een leidinggevende zich aan zijn/haar beloften houdt en moraliteit toont. Begeleiden van ethisch gedrag kan door communiceren over de regels betreffende integriteit en het belonen van ethisch verantwoordelijk gedrag van medewerkers. Ook is het voor medewerkers van belang dat helder is welke eisen aan hen gesteld worden en hoe zij succesvol kunnen bijdragen doordat de verwachtingen, rechten en plichten helder zijn. Ethische leidinggevenden delegeren beslissingen en verantwoordelijkheden en geven mensen inspraak. Bij het nemen van beslissingen denken ethische leidinggevenden niet alleen aan zichzelf en hun werkgroep, maar ook aan bredere belangen in de omgeving zoals het milieu. In tabel 1 staan ter verheldering de gedragsdimensies van ethisch leiderschap weergegeven met voor elke dimensie een voorbeeldstelling. ${ }^{1}$

\subsection{Operationalisering en onderzoek}

Als het ethisch leiderschap van belang is voor het vertrouwen en de weerbaarheid van de organisatie tegen onethisch gedrag, dan is het vervolgens van belang om ethisch leiderschap te kunnen meten. Op basis van de gepresenteerde gedragsdimensies is in Nederland een vragenlijst ontwikkeld om ethisch leiderschap te meten, de zogeheten Ethisch Leiderschap op het Werk (ELW)vragenlijst (Kalshoven et al., 2010). Ethisch leiderschap wordt in meetinstrumenten meestal geoperationaliseerd als gedrag dat door de direct aangestuurde werknemers wordt waargenomen. De percepties van potentiële andere belanghebbenden, zoals consumenten, worden tot nu toe niet betrokken in het meten van ethisch leiderschap.

Ethisch leiderschap is niet alleen belangrijk in de top van de organisatie, maar ook een vorm van leiderschapsgedrag die lager in de organisatie van belang is. Uit gesprekken met managementteams blijkt dat zij vaak een positiever beeld hebben van het ethisch gedrag van leidinggevenden dan werknemers rapporteren in de ethisch-leiderschapsvragenlijst. Ook blijkt dat leidinggevenden vaak zelf een positiever beeld hebben van hun eigen ethische-leiderschapsstijl in vergelijking met de percepties van werknemers. Belangrijk is dus bij de terugkoppeling van het ethisch leiderschapsgedrag aan de organisatie dat werknemers anoniem blijven. Een voordeel van vragenlijstonderzoek naar een sensitief onderwerp als ethiek is dat anonimiteit gewaarborgd blijft.

De resultaten van de ELW-vragenlijst kunnen laten zien wat de weerbare en kwetsbare aspecten van het ethisch leiderschap zijn. Voor het interpreteren van de resultaten ontbreekt een norm of een standaard om te bepalen of de resultaten voldoende ethisch zijn. De interpretatie zal afhangen van de situatie van de organisatie en het oordeel van het management. Ethiek is wat de organisatie en de medewerkers afspreken wat juist is en kan dus per organisatie verschillen met in ogenschouw nemend wat in het maatschappelijke verkeer aanvaardbaar is.

Om de waarde van de vragenlijst te laten zien, worden in dit artikel gegevens gepresenteerd van zo'n 750 werknemers die vragen hebben beantwoord over het ethisch gedrag van hun leidinggevende. Het gaat om een leidinggevende die de werknemers dagelijks aanstuurt en begeleidt. De werknemers werken in verschillende organisaties in Nederland. De vragenlijsten zijn ingevuld tussen 2007 en 2009. 
Tabel 2 Ethisch leiderschapsgedrag

\begin{tabular}{|l|c|c|c|c|}
\hline \multicolumn{1}{|c|}{ Ethisch leiderschapsgedrag } & Gemiddelde score & Standaarddeviatie & Minimale score & Maximale score \\
\hline Rechtvaardigheid en eerlijkheid & 3,7 & 0,69 & 1,3 & 5,0 \\
\hline Integriteit & 3,8 & 0,81 & 1,0 & 5,0 \\
\hline Zorgzaamheid & 3,7 & 0,73 & 1,0 & 5,0 \\
\hline Delen van beslissingen & 3,6 & 0,63 & 1,3 & 5,0 \\
\hline Begeleiden van ethisch gedrag & 3,4 & 0,65 & 1,5 & 5,0 \\
\hline Verduidelijken van rechten en plichten & 3,7 & 0,64 & 1,8 & 5,0 \\
\hline Aandacht voor milieuzaken & 3,0 & 0,74 & 1,0 & 5,0 \\
\hline Ethisch leiderschap totaal & 3,6 & 0,52 & 2,0 & 5,0 \\
\hline
\end{tabular}

$N=747$ werknemers

De antwoordschaal loopt van 1 (helemaal mee oneens) tot 5 (helemaal mee eens).

In tabel 2 staan de gemiddelden en de minimale en maximale scores van het gedrag van leidinggevenden op een schaal van 1 tot 5 zoals waargenomen door medewerkers. Opvallend is dat de resultaten tonen dat de minimale scores op alle zeven de gedragsdimensies laag zijn (2.0 of lager). Dit betekent dat er medewerkers zijn die helemaal niet of zeer weinig ethisch leiderschap van hun leidinggevende waarnemen. Verder valt de gemiddelde score van leidinggevenden voor aandacht voor milieuzaken op. Deze score is precies 3.0 en valt in het midden van de schaal. De overheid voert al jaren campagne op dit vlak, maar het lijkt erop dat veel werknemers vinden dat er niet veel aandacht is voor milieu in hun team. Voor wat milieuzaken betreft, valt er dus voornamelijk in de dagelijkse werkzaamheden een slag te maken. Ten slotte varieert de score op integriteit en beoordelen medewerkers hun leidinggevende gemiddeld als redelijk integer (3.8). Wellicht komt deze variatie voort uit het gegeven dat vele organisaties gedragscodes opstellen, deze eenmalig communiceren en verder het onderwerp loslaten.

\subsection{De theoretische basis: 'social learning' en 'social exchange'}

In de wetenschappelijke literatuur over ethisch leiderschap zijn tot nu toe twee perspectieven gebruikt om te verklaren waarom ethisch leiderschapsgedrag een positieve invloed zou hebben op werknemers, de zogenoemde 'social learning'- en 'social exchange'-theorieën. Brown et al. (2005) beargumenteren dat ethische leidinggevenden een voorbeeldfunctie hebben en dat werknemers geneigd zijn gedrag van de leidinggevende na te bootsen. Volgens het 'social learning'-perspectief kunnen werknemers leren van het observeren van het gedrag van leiders en de consequenties van dit gedrag (Bandura, 1986). Leidinggevenden kunnen ethische gedragingen van werknemers dus stimuleren door bewust het juiste voorbeeld te geven. Ethisch gedrag stimuleren bij werknemers kan ook door transparantie en goede communicatie tussen leider en werknemer. Daarnaast benadrukt dit perspectief dat leidinggevenden er voor kunnen zorgen dat gestelde ethische standaarden gehandhaafd blijven door het belonen van gewenst gedrag en het afkeuren van ongewenst gedrag. Werknemers leren wat gewenst gedrag is doordat zij luisteren, zien en ervaren hoe zijzelf of andere werknemers beloond of gestraft worden (Brown et al., 2005).

Leidinggevenden hebben een voorbeeldfunctie door de rol die zij innemen, de status die zij hebben binnen de organisatie en de macht die zij bezitten om het gedrag van anderen te beïnvloeden. In lijn hiermee vinden wij in een onderzoek dat ethische leidinggevenden als prototypisch worden ervaren (Kalshoven en Den Hartog, 2009). Met leiderschapsprototypiciteit wordt bedoeld dat de leidinggevende het meest representatief is voor de groepsidentiteit. Groepsleden zullen voor het gewenste gedrag naar het individu kijken die het meest representatief is en dat is dus de leidinggevende. Prototypische leiders zorgen dat werknemers zich identificeren met hun groep en hebben daardoor meer aandacht voor de attitudes en gedragingen van andere groepsleden.

Ethisch leiderschap wordt tevens benaderd vanuit de sociale uitwisselingsgedachte. De 'social exchange'-theorie gaat uit van het opbouwen van een relatie gebaseerd op vertrouwen tussen leidinggevenden en hun werknemers (bijv. Mayer et al., 2010; Turner et al., 2002). De relatie tussen leidinggevenden en hun werknemers zal versterken als de leidinggevenden hun werknemers eerlijk, open en met respect en zorg behandelen. Een dergelijke sterke relatie makkt dat werknemers bereid zijn om de positieve behandeling door een leidinggevende te belonen door ook positief gedrag te vertonen. Dus beide partijen moeten investeren in de relatie. De bereidheid van werknemers om 
positief gedrag te vertonen, ontstaat door het gevoel van een persoonlijke verplichting (gebaseerd op de norm van wederkerigheid; Blau, 1964). Onderling vertrouwen is belangrijk in sociale uitwisselingssituaties. Diverse onderzoeken laten een positief verband zien tussen ethisch leiderschap en het vertrouwen van werknemers in hun leidinggevenden (Brown et al., 2005; Kalshoven et al., 2010; Kalshoven en Den Hartog, 2009). Het vertrouwen in hun leidinggevende leidt bij medewerkers tot de overtuiging dat extra inspanningen op een bepaald moment beloond zullen worden, zelfs zonder expliciete afspraken daarover. De transacties tussen leidinggevende en werknemer zijn dus niet noodzakelijkerwijs van tevoren gespecificeerd, waardoor vertrouwen extra belangrijk is vanuit de 'social exchange'-gedachte. Deze sociale uitwisselingen zijn gericht op de lange termijn, omdat het tijd kost om een relatie op basis van vertrouwen op te bouwen. Dit zal ook helpen bij het voorkomen van informatieasymmetrie doordat leidinggevenden in deze relaties informatie zo veel mogelijk delen.

In tegenstelling tot een sociale uitwisseling is er bij een economische uitwisseling geen vertrouwen vereist als voorwaarde voor een uitwisseling. Dat wordt verklaard doordat een economische uitwisseling tussen bijvoorbeeld een leidinggevende en een werknemer op één bepaald moment plaatsvindt. In een sociale uitwisseling is er geen garantie dat een werknemer het ethische gedrag van een leidinggevende als het ware terugbetaalt met gewenst gedrag. Als deze uitwisseling niet plaatsvindt, is daarmee het vertrouwen van de leidinggevende geschaad. Deze actie kan een conflict veroorzaken en de relatie tussen leidinggevende en werknemer beschadigen (Gouldner, 1960). Het gevolg zal een 'economic exchange' zijn. Hierbij draait het om positief gedrag vertonen op basis van financiële stimuli en dit is in vergelijking tot een sociale uitwisseling gericht op de korte termijn. Economische uitwisseling kan gewenst zijn in situaties met een hoge mate van onzekerheid of risico.

\section{Uitkomsten van ethisch leiderschap}

Uitkomsten van ethisch leiderschapsgedrag omvatten zowel attitudes als gedrag van werknemers en soms wordt zelfs gezegd dat er een positief effect zal zijn op organisatieprestaties (Aronson, 2001; Brown et al., 2005; Kanungo, 2001). Echter, empirische kennis over de effecten van ethisch leiderschap op organisatieniveau is schaars. Uit diverse onderzoeken blijkt dat ethisch leiderschapsgedrag positief samenhangt met attitudes van werknemers. Brown et al. (2005) vinden dat ethisch leiderschap positief samenhangt met bereidheid van medewerkers om problemen aan het managementteam te rapporteren en bereidheid van werknemers om extra energie in hun werk te stoppen.
Ook vinden Den Hartog en De Hoogh (2009) een samenhang tussen ethisch leiderschap en vertrouwen in management en collega's. Aanvullend vinden zij een positief verband tussen ethisch leiderschap en normatieve en affectieve commitment. Een werknemer die een hoge mate van affectieve commitment ervaart, is emotioneel betrokken bij de organisatie en zijn doelen en wil graag bij de organisatie blijven werken. Bij normatieve commitment voelt een werknemer een verplichting om bij de organisatie te blijven door bijvoorbeeld de sociale uitwisselingsrelatie met de leidinggevende. Ethisch leiderschap blijkt ook positief gerelateerd aan optimisme over de toekomst en effectiviteit van het topmanagementteam (De Hoogh en Den Hartog, 2008). Ten slotte vinden verscheidene onderzoeken een positieve relatie tussen ethisch leiderschap en werknemerstevredenheid en leiderschapseffectiviteit (Brown et al., 2005; De Hoogh en Den Hartog, 2009; Kalshoven en Den Hartog, 2009; Kalshoven et al., 2010).

Recentelijk is er ook onderzoek gedaan naar de positieve invloed van ethisch leiderschap op het gedrag van werknemers. Uit deze onderzoeken blijkt dat ethisch leiderschapsgedrag positief samenhangt met samenwerken of prosociaal gedrag op zowel individueel als groepsniveau (Kalshoven et al., 2010; Mayer et al., 2009; Piccolo et al., 2010). Deze gedragen worden gezien als ethisch, omdat een individu ervoor kan kiezen om gedrag te vertonen dat een voordeel heeft voor anderen en niet per definitie voor zichzelf(Graham 1995). Samenwerking betekent in dit geval de bereidheid om collega's te helpen en vriendelijk en onderling behulpzaam zijn. Dit gedrag is werkgerelateerd en voorbeelden van dit gedrag zijn nieuwe medewerkers helpen of het helpen van medewerkers die een hoge werklast hebben. Een ethische leider lijkt voor een betere samenwerking in een team te zorgen. Naast deze meer affectieve vorm van gedrag blijkt ethisch leiderschap ook veranderingsgeoriënteerde vormen van gedrag positief te beïnvloeden, zoals proactief werkgedrag en het uiten van een mening (Kalshoven, 2010; Walumbwa en Schaubroeck, 2009). Proactiviteit betekent dat een individu in actie komt om veranderingen teweeg te brengen en dus niet alleen reageert op veranderingen - als deze al plaatsvinden. Van dit soort affectieve en veranderingsgeoriënteerde vormen van werknemersgedrag is bekend dat zij indirect bijdragen aan de effectiviteit van de organisatie (zie bijvoorbeeld Borman en Motowidlo, 1993).

Hebben nu alle aspecten van dit type leiderschap dezelfde effecten? Om meer te weten te komen over welke specifieke elementen van ethisch leiderschapsgedrag invloed hebben op het gedrag en de attituden van werknemers, zullen de zeven dimensies van ethisch leiderschap hier worden besproken. Hoewel in onderzoek alle zeven ethisch- 
leiderschapsdimensies positief blijken bij te dragen aan de attitudes van werknemers, zoals een verminderd cynisme en een verhoogde commitment, tevredenheid, vertrouwen en leiderschapseffectiviteit (zie Kalshoven, 2010; Kalshoven et al., 2010), zijn er ook verschillen. De Hoogh en Den Hartog (2008) vinden bijvoorbeeld dat de twee dimensies 'eerlijkheid en rechtvaardigheid' en 'het verhelderen van rechten en plichten' positief samenhangen met effectiviteit van het managementteam. De dimensie 'het delen van beslissingen, macht en verantwoordelijkheid' blijkt echter niet van belang in relatie tot effectiviteit van het managementteam. De zeven leiderschapsdimensies dragen tevens wisselend bij aan het verklaren van het gedrag van werknemers. Voor de affectieve vormen van werknemersgedrag lijken voornamelijk de dimensies 'rechtvaardigheid en eerlijkheid', 'zorgzaamheid' en 'het delen van beslissingen, macht en verantwoordelijkheid' van belang (Kalshoven et al., 2010). Het lijkt dus relevant om de effecten van de verschillende ethisch-leiderschapsdimensies op werknemersgedrag nader te onderzoeken. Tot op heden sluit het onderzoek over ethisch leiderschap en werknemerattitude en -gedrag aan bij eerder leiderschapsonderzoek. Dit heeft te maken met de nog weinig valide meetinstrumenten op het gebied van ethiek op het werk. Het onderzoeksgebied kan een stap voorwaarts maken door meer te focussen op ethische aspecten van het werk.

\section{Antecedenten van ethisch leiderschap}

In de bestaande theorieën over ethisch leiderschap worden situationele en individuele karakteristieken als belangrijke invloeden gezien op het ontstaan van ethisch leiderschap (Brown en Treviño, 2006). Er is echter nog vrij weinig onderzoek naar de antecedenten van ethisch leiderschap gedaan. Twee recente studies hebben de relatie tussen karaktertrekken van de leidinggevende en percepties van ethisch leiderschapsgedrag door medewerkers onderzocht. Daarbij zijn de vijf basale persoonlijkheidstrekken van mensen die relatief stabiel zijn over tijd en situaties bekeken, te weten neuroticisme, extraversie, openheid voor ervaringen, vriendelijkheid en consciëntieusheid. Voorgaande studies hebben deze basale persoonlijkheidstrekken al gerelateerd aan effectiviteit van leidinggevenden (bijv. Bono en Judge, 2004). Drie van de vijf basale trekken blijken belangrijk te zijn voor ethische leidinggevenden, namelijk relatief hoge consciëntieusheid en vriendelijkheid en laag neuroticisme (Kalshoven, 2010; Walumbwa en Schaubroeck, 2009). Deze gevonden verbanden zijn niet sterk, maar lijken wel stabiel.

Consciëntieusheid staat voor verantwoordelijkheid, plichtsgetrouwheid en attentheid (McCrae en Costa, 1987). Mensen die hoog scoren op consciëntieusheid houden zich aan regels en afspraken. Consciëntieusheid maakt dat leidinggevenden zich eerlijk en rechtvaardig gedragen, regels en procedures duidelijk maken en anderen daar ook op wijzen. Leidinggevenden die hoog scoren op consciëntieusheid zullen als ethisch worden ervaren, bijvoorbeeld doordat zij zich eerlijk en betrouwbaar gedragen en omdat zij verwachtingen en verantwoordelijkheden verhelderen (Kalshoven, 2010; Walumbwa en Schaubroeck, 2009).

Vriendelijkheid als karaktertrek staat voor warm, genereus, altruïstisch, betrouwbaar en de mate waarin iemand het belang van anderen boven eigen belang stelt (McCrae en Costa, 1987). Vertrouwen, vriendelijkheid en integriteit zijn onderdeel van deze karaktertrek. Deze karaktertrek zullen ethische leidinggevenden uiten in de vorm van bezorgdheid en het geven om anderen en het vertonen van consistent gedrag. Leidinggevenden die hoog scoren op vriendelijkheid worden als ethisch ervaren door hun werknemers (Kalshoven, 2010; Walumbwa en Schaubroeck, 2009).

De twee studies laten een wisselend beeld zien betreffende neuroticisme. De karaktereigenschap neuroticisme staat voor de mate waarin een persoon emotioneel op tegenslagen reageert. Angst, impulsiviteit, kwetsbaarheid en stemmingswisselingen vallen onder neuroticisme (McCrae en Costa, 1987). De studie van Walumbwa en Schaubroeck (2009) vindt geen verband tussen ethisch leiderschap en neuroticisme. Echter, de studie van Kalshoven (2010) toont wel een verband. Dit verband valt te verklaren doordat leidinggevenden die hoog scoren op neuroticisme minder stabiel gedrag laten zien en daardoor minder goed een voorbeeldfunctie kunnen vervullen. Toekomstig onderzoek zal moeten uitwijzen onder welke omstandigheden neuroticisme relateert aan ethisch leiderschap.

Gerelateerd onderzoek naar antecedenten van ethisch leiderschap laat zien dat het niveau van de cognitieve ontwikkeling op het gebied van ethiek (cognitive moral development) samenhangt met ethisch leiderschapsgedrag (Turner et al., 2002). Individuen die hoog scoren op de cognitieve ontwikkeling op het gebied van ethiek kunnen ethische dilemma's herkennen, weten het verschil tussen goed en fout en vertonen meer ethisch gedrag (Kohlberg, 1969). Ook eerder onderzoek van Weber (1990) toont dat managers vaak hoog scoren op morele oordeelsvorming. Tevens tonen De Hoogh en Den Hartog (2008) aan dat sociale verantwoordelijkheid als persoonlijkheidstrek en ethisch leiderschap samenhangen. Onder sociale verantwoordelijkheid valt verantwoordelijkheid nemen, zich bewustzijn zijn van de consequenties van genomen acties, betrouwbaar overkomen en controle hebben over het getoonde gedrag (Winter, 1991). Leidinggevenden die meer sociaal verantwoordelijk zijn, worden als ethisch ervaren. 
Mayer et al. (2009) hebben tot nu toe als enigen situationele factoren als antecedenten van ethisch leiderschap onderzocht. Zij vonden dat het voorbeeldgedrag van het managementteam invloed lijkt te hebben op de dagelijkse leidinggevenden en daardoor op het gedrag van werknemers. Dit betekent dat leidinggevenden lager in de organisatie het managementteam volgen in wat gewenst gedrag is. Echter, een kanttekening bij dit onderzoek is dat door de onderzoeksopzet causaliteit niet vast te stellen is. Eigenlijk weten we dus nog weinig over waarom leidinggevenden besluiten om ethisch dan wel onethisch gedrag te vertonen. Persoonlijkheid lijkt een kleine, maar belangrijke rol te spelen. Toekomstig onderzoek is nodig om meer te leren over antecedenten van ethisch leiderschap. De eerdergenoemde situationele factoren zijn bijvoorbeeld ook zelden onderzocht. Daarnaast beargumenteren Brown en Treviño (2006) dat bijvoorbeeld de ethische context van een organisatie invloed kan hebben op het ethische gedrag van leidinggevenden.

\section{Conclusie}

Het doel van dit artikel is om een overzicht te geven en het belang aannemelijk te maken van het nog jonge onderzoeksveld van ethisch leiderschap. De onderzoeksbevindingen tot nu toe laten zien dat ethisch leiderschap een belangrijke bijdrage levert aan het stimuleren van positief werkgedrag en attitudes van medewerkers. Ervaringen met diverse organisaties leren dat het niet gemakkelijk is om met onderwerpen als integriteit en ethiek aan de slag te gaan. Ook blijkt dat organisaties niet goed weten hoe de vraagstukken over dit onderwerp aan te pakken. Onderzoeken op dit gebied laten zien dat het ethisch handelen van leidinggevenden voor direct aangestuurde werknemers wel degelijk van belang is voor het functioneren op de werkvloer. Het lijkt daarom voor organisaties de moeite waard om hierin te investeren. De ontwikkelde ELW-vragenlijst om ethisch leiderschapsgedrag aan de hand van zeven gedragsdimensies te meten, kan hierbij ondersteunen. Het instrument kan organisaties inzicht geven in het niveau van het ethische gedrag van leidinggevenden. Aan de hand van deze inzichten kunnen specifieke trainingen en ontwikkelingsmogelijkheden geboden worden om de positieve effecten van ethisch leiderschapsgedrag maximaal te benutten. Zoals besproken gaat het om een interne discussie in organisaties om te bepalen wat ethisch gedrag is. Schminke et al. (2007) adviseren dan ook om trainingen niet alleen over de integriteitcodes, regels en procedures te laten gaan, maar ook juist over het informele 'grijze' gebied. Suggesties voor trainingsmogelijkheden in dit grijze gebied zijn rollenspellen, interactieve video's of scenario's (Schminke et al., 2007). Dergelijke trainingen zorgen voor ervaringen met ethische dilemma's op het werk. Ook kunnen training en coaching van leidinggevenden hen bewuster maken van hun voorbeeldfunctie en hen helpen in het opbouwen van een vertrouwensband met werknemers.

Het toezicht houden op integriteit lijkt moeilijk, voornamelijk ook door het subjectieve karakter (KPMG, 2010). Echter, een voorbeeldfunctie van het gewenste gedrag van leidinggevenden in de organisatie blijkt belangrijk. Voor organisaties ligt er de uitdaging om te zorgen dat leidinggevenden en werknemers zich ethisch gedragen. We hebben in Nederland een model ontwikkeld om meerdere facetten van het ethisch leiderschapsconcept te kunnen meten. De mogelijkheid tot het in kaart brengen van ethisch leiderschap kan het onderwerp duidelijker op de kaart zetten en verdere stappen op het gebied van ontwikkeling, training en selectie van ethische leidinggevenden stimuleren.

Drs. Karianne Kalshoven promoveert op 16 juni 2010 op ethisch leiderschapsgedrag aan de Universiteit van Amsterdam Business School en startte per 1 april 2010 als onderzoeker aan het Ethiek Instituut van de Universiteit Utrecht. Haar onderzoeksinteresses betreffen onder meer ethisch en sustainable leiderschap in organisaties.

Prof. dr. Deanne N. den Hartog is hoogleraar

Organisatiegedrag en hoofd van de HRM-OB-sectie aan de

Universiteit van Amsterdam Business School. Haar

onderzoek richt zich op ethisch, charismatisch en

crosscultureel leiderschap, HRM en proactief en coöperatief werkgedrag.

Dr. Annebel H.B. de Hoogh is universitair docent aan de Arbeids- en Organisatiepsychologieafdeling van de Universiteit van Amsterdam. Haar expertises zijn onder andere charismatisch, ethisch en narcistisch leiderschap en de rol van persoonlijkheid in leiderschap.

Noot

De volledige vragenlijst is voor het doen van wetenschappelijk onderzoek vrij beschikbaar bij de auteurs. 
-Aronson, E. (2001), Integrating leadership styles and ethical perspectives, Canadian Journal of Administrative Sciences, vol. 18, pp. 244-256.

- Bandura, A. (1986), Social foundation of thought and action, Englewood Cliffs, New Jersey: Prentice-Hall.

Blau, P. (1964), Exchange and power in social life, New York: Wiley \& Sons.

- Bono, J.E. en T.A. Judge (2004), Personality and transformational and transactional leadership: A meta-analysis, Journal of Applied Psychology, vol. 89, pp. 901-910.

- Borman, W.C. en S.J. Motowidlo (1993), Expanding the criterion domain to include elements of contextual performance, in: $\mathrm{N}$. Schmitt, W.C. Borman, en associates (eds.), Personnel selection in organizations (pp. 71-98), San Francisco, CA: Jossey-Bass. Brown, M. E. en L. K. Treviño (2006), Ethical leadership: A review and future directions, The Leadership Quarterly, vol. 17, pp. 595-616.

Brown, M. E., L. K. Treviño, en D.A. Harrison, (2005), Ethical leadership: A social learning perspective for construct development and testing, Organizational Behavior and Human Decision Processes, vol. 97, pp. 117-134. - Ciulla, J. B. (2004), Ethics and leadership effectiveness, in: J. Antonakis, A. T. Cianciolo, en R. J. Sternberg (eds.), The Nature of Leadership (pp. 302-328), Thousand Oaks, CA: Sage Publications.

De Hoogh, A. H. B. en D. N. den Hartog (2008), Ethical and despotic leadership, relationships with leader's social responsibility, top management team effectiveness and subordinates' optimism: A multi-method study, The Leadership Quarterly, vol. 19, pp. 297-311.

- De Hoogh, A. H. B. en D. N. den Hartog, (2009), Ethical leadership: The socially responsible use of power, in: D. Tjosvold en B.M. van Knippenberg (eds.), Power and interdependence in organizations (pp. 338354), Cambridge: University Press.

Den Hartog, D. N. en A.H.B. de Hoogh (2009), Empowerment and leader fairness and integrity: Studying ethical leader behavior: From a levels-of-analysis perspective, European Journal of Work and Organizational Psychology, vol. 18, pp. 199-230.

- Dickson, M., D.B. Smith, M. Grojean en M.
Ehrhart (2001), An organizational climate regarding ethics: The outcome of leader values and the practices that reflect them, The Leadership Quarterly, vol. 12, pp. 197-218.

Ernst \& Young (2009), European fraud survey 2009, 'Is integrity a casualty of the downturn?', Ernst \& Young, Fraud Investigation \& Dispute Services.

Gouldner, A.W. (1960), The norm of reciprocity: A preliminary statement, American Sociological Review, vol. 25, pp. 161-178.

- Graham, J.W. (1995), Leadership, moral development, and citizenship behavior, Business Ethics Quarterly, vol. 55, pp. 43-54.

- Kalshoven, K. (2010), Ethical leadership at work, dissertation, unpublished.

- Kalshoven, K. en D.N. den Hartog, (2009). Ethical leader behavior and leader effectiveness: The role of prototypicality and trust, International Journal of Leadership Studies, vol. 5, pp. 102-119.

- Kalshoven, K., D.N. den Hartog en A.H.B. de Hoogh (2010), Ethical leadership at work questionnaire (ELW): Development and validation of a multidimensional measure, The Leadership Quarterly, in druk.

- Kanungo, R.N. (2001), Ethical values of transactional and transformational leaders, Canadian Journal of Administrative Sciences, vol. 18, pp. 257-265.

- Kaptein, M. (2005), Een deugdenleer van de controleur. Een inventarisatie van morele dilemma's en kernkwaliteiten, Maandblad voor Accountancy en Bedrijfseconomie, vol. 79, no. 1/2, pp. 41-49.

- Kaptein, M., R. Rozekrans en R. de Groot (2005), Integriteitklimaat als auditobject. Maandblad voor Accountancy en Bedriffseconomie, vol. 79, no. 10, pp. 466-474. - Kohlberg, L. (1969), Stage and sequence: The cognitive-developmental approach to socialization, in: D. A. Golsin (Ed.), Handbook of socialization theory and research (pp. 347480), Chicago: Rand McNally.

- KPMG (2010), Onderzoek integriteittoezicht onder Raad van Commissarissen; zie: www. kpmg.nl/Docs/Corporate_Site/Publicaties/ Integriteittoezicht_RvC.pdf.

- Mayer, D.M., M. Kuenzi, R. Greenbaum, M. Bardes en R. Salvador (2009), How low does ethical leadership flow? The relative effects of top management and supervisors on employee ethical behaviors and job attitudes, Organizational Behavior and Human Decision Processes, vol. 108, pp. 1-13.

- McCrae, R.R. en P.T. Costa Jr. (1987), Validation of the five-factor model of personality across instruments and observers, Journal of Personality and Social Psychology, vol. 52, pp. 81-90.

-Piccolo, R.F., R. Greenbaum, D.N. den Hartog en R. Folger (2010), Task significance and job autonomy as motivational mechanisms in the ethical leadership process, Journal of Organizational Behavior, vol. 31, pp. 259-278.

- Resick, C.J., P.J. Hanges, M.W. Dickson en J.K. Mitchelson (2006), A cross-cultural examination of the endorsement of ethical leadership, Journal of Business Ethics, vol. 63, pp. 345-359.

- Schminke, M., A. Arnaud en M. Kuenzi (2007), The power of ethical work climates, Organizational Dynamics, vol. 36, pp. 171-186.

- Treviño, L.K., M. Brown en L.P. Hartman (2003), A qualitative investigation of perceived executive ethical leadership: Perceptions from inside and outside the executive suite, Human Relations, vol. 56, pp. 5-37.

- Turner, N., J. Barling, O. Epitropaki, V. Butcher en C. Milder (2002), Transformational leadership and moral reasoning, Journal of Applied Psychology, vol. 87, pp. 304-311.

- Walumbwa, F.O., B.J. Avolio, W.L. Gardner, T.S. Wernsing en S.J. Peterson (2008), Authentic leadership: Development and validation of a theory-based measure, Journal of Management, vol. 34, pp. 89-126.

- Walumbwa, F.O. en J. Schaubroeck (2009), Leader personality traits and employee voice behavior: Mediating roles of ethical leadership and workgroup psychological safety, Journal of Applied Psychology, vol. 94, pp. 1275-1286.

- Weber, J. (1990), Managers' moral reasoning: assessing their responses to three moral dilemmas, Human Relations, vol. 43, pp. 687-702.

- Winter, D.G. (1991), A motivational model of leadership: Predicting long-term management success from TAT measures of power motivation and responsibility, The Leadership Quarterly, vol. 2, pp. 67-80. 